\title{
Pengembangan Metode Spektrofotometer UV-Vis Untuk Menentukan Kadar Boraks Dengan memanfaatkan Senyawa antosianin dari Ekstrak Buah Naga Sebagai Indikator
}

\author{
Siti khomsiyah, Qurrata Ayun, Reni Evi Eka Susanti
}

Program Studi Kimia, Fakultas Matematika dan Ilmu Pengetahuan Alam Universitas PGRI Banyuwangi

Email korespondensi*: qu_rrata@yahoo.co.id

\begin{abstract}
ABSTRAK
Saat mengolah makanan selalu diusahakan untuk menghasilkan produk makanan yang disukai dan bermutu baik serta aman untuk dikonsumsi. Akhir - akhir banyak pengusaha pangan yang umumnya dibuat oleh industry kecil atau rumah tangga mulai banyak menggunakan boraks untuk penambahan pada bahan makanan. Penggunaan boraks sebagai pengawat makanan dapat menyebabkan mual, muntah, diare dan lain - lain. Bagi yang mengkonsumsinya untuk jangka panjang dapat menyebabkan penyakit kanker, sebab zat pengawet tersebut sulit diuraikan oleh tubuh (Asterina, dkk). Dengan adanya kasus tersebut maka peneliti ingin mengembangkan metode untuk mendeteksi boraks pada sampel cilok yang beredar di jalan raya Kota Banyuwangi menggunakan spektrofotometer UV-Vis dengan memanfaatkan senyawa antosianinya dari kulit buah naga merah untuk digunakan sebagai indikator warna. Dalam penelitian ini dapat diketahui bahwa senyawa Antosianin stabil pada waktu 0 sampai 45 menit, dan Senyawa Antosianin stabil Pada pH 3 (pH asam), kemudian pada uji panjang gelombang maksimum diperoleh panjang gelombang $(\lambda)=564 \mathrm{~nm}$ dan diperoleh kurva kalibrasi dengan regresi $\mathrm{y}=0.0018 \mathrm{x}+0.002$ dengan $\mathrm{R}^{2}=0.996$. Hasil validasi secara kualitatif dan kuantitaif sampel cilok yang beredar di jalan raya Kota Banyuwangi positif mengandung boraks, uji validasi tersebut menunjukkan bahwa semua metode yang telah dilakukan valid. Sehingga dapat dilakukan penetapan kadar boraks pada sampel cilok. Dari hasil penelitian ini, sampel cilok A dan cilok B positif mengandung borak dengan total $17.5 \mathrm{ppm}$ pada cilok $\mathrm{A}$, dan $76 \mathrm{ppm}$ pada cilok B.
\end{abstract}

Kata Kunci : Boraks, Kulit Buah Naga Merah, Antosianin, Spektofotometer UV-Vis

\section{PENDAHULUAN}

Dewasa ini penggunaan bahan tambahan makanan yang terlarang masih sering ditemukan, bahkan semakin meningkat terutama pada pengusaha pangan yang umumnya dihasilkan oleh industri kecil atau rumah tangga. 
Boraks merupakan kristal lunak tidak berwarna atau serbuk hablur putih dan tidak berbau. Larutannya bersifat basa terhadap fenoftalen. Pada udara kering merapuh. Hablur sering dilapisi serbuk warna putih. Larut dalam 20 bagian air, praktis tidak larut dalam etanol(Winarno,1994).

Cilok yang mengandung boraks teksturnya lebih kenyal, bila digigit akan kembali ke bentuk semula dan warnanya akan tampak lebih putih. Ini berbeda dengan cilok yang baik, yang biasanya berwarna abu-abu segar merata pada semua bagian baik dipinggir maupun ditengah. cilok dengan warna abu-abu tua menandakan cilok tersebut dibuat dengan tambahan obat bakso yang berlebihan.

Berdasarkan hal tersebut, maka diperlukan identifikasi dan penetapan kadar boraks pada makanan yang dijual bebas di beberapa titik jalan di Kota Banyuwangi. Dengan memperhatikan sifat asam boraks yang berupa hablur transparan tidak berwarna, peneliti ingin memanfaatkan ekstrak kulit buah naga merah yang mengadung antosianin sebagai indikator warna.

Kulit buah naga merah memiliki kandungan nutrisi, seperti karbohidrat, lemak, protein dan serat pagan. Ekstrak dari kulit buah naga merah ini ternyata mengandung kadar antosianin 26,4587 ppm. Antosianin merupakan zat warna yang berperan untuk memberikan warna merah, yang berpotensi untuk digunakan sebagai zat pewarna alami untuk pangan dan dapat juga dijadikan sebagai alternatif pengganti warna sintetis yang lebih aman bagi kesehatan (Citramukti, 2008).

Antosianin yang terdapat pada kulit buah naga merah dapat digunakan untuk mendeteksi kandungan boraks dan formalin yang terdapat pada makanan. Hasil ekstraksi antosianin dari kulit buah naga ini selanjutnya akan digunakan sebagai indikator warna pada analisis boraks. Tujuan penelitian ini yaitu untuk mengetahui kandungan dan kadar boraks pada cilok yang berada di kota banyuwangi. Berdasarkan latar belakang diatas peneliti ingin mengetahui kandungan dan kadar boraks pada cilok yang barada di kota banyuwangi dengan menggunakan ekstrak kulit buah naga sebagai indikator.

\section{METODE PENELITIAN}

\section{Alat dan Bahan}

Bahan yang digunakan pada penelitian ini antara lain adalah kulit buah naga merah, aquadest, $\mathrm{NaOH}, \mathrm{KCl}$, asam sitrat, $\mathrm{CH}_{3} \mathrm{COONa}$, asam boraks $\left(\mathrm{H}_{3} \mathrm{BO}_{3}\right)$, buffer phospat 0.1 $\mathrm{M}, \mathrm{H}_{2} \mathrm{SO}_{4}$. 
Alat-alat yang digunakan adalah pisau, stoples, gelas beaker, neraca analitik, alumunium foil, botol vial gelap, botol semprot, corong pisah, $\mathrm{pH}$ meter, batang pengaduk, pipet mikro, pipet tetes, pipet ukur, labu ukur, gelas ukur, tabung reaksi, spektrofotometer UV Visible, stopwatch, Termometer, kompresor, erlenmeyer, kertas saring whatman.

\section{Metodologi}

Dilakukan uji warna golongan senyawa antosianin menurut Harborne (1987) yakni 0,5 gram ekstrak etanol kulit buah naga ditambahkan $\mathrm{HCl} 2 \mathrm{M}$ kemudian dipanaskan $100{ }^{\circ} \mathrm{C}$ selama 5 menit.. Penetapan antosianin dilakukan dengan metode perbedaan $\mathrm{pH}$ yaitu $\mathrm{pH}$ 1dan $\mathrm{pH} 4,5$. Pada $\mathrm{pH} 1$ antosianin akan berbentuk senyawa oxonium, sedangkan pada $\mathrm{pH}$ Ekstrak kulit buah naga merah sebanyak $3 \mathrm{~mL}$, kemudian ditambah dengan $6 \mathrm{~mL}$ buffer phosphate $0.1 \mathrm{M}$ dengan variasi $\mathrm{PH}(3,4,5,5,6,7,8,9,10,11,12)$, kemudian dikocok hingga tercampur rata, kemudian di ukur untuk menentukan panjang gelombang $(\lambda)$ maksimum dari $(\lambda)$ 400-700 $\mathrm{nm}$ dengan interval $20 \mathrm{~nm}$ dan $2 \mathrm{~nm}$, dengan menggunakan blanko sesuai dengan variasi PH yang di ukur.

Sebanyak $1 \mathrm{~mL}$ ekstrak buah naga merah dimasukkan kedalam tabung reaksi, ditambahkan 2 mL buffer phosphate pH 12 dikocok hingga homogen, kemudian ditambah dengan larutan asam boraks 50 ppm dikocok hingga homogen dan didiamkan selama \pm 15 menit. Selanjutnya larutan diukur absorbansinya pada panjang gelombang 450 - $700 \mathrm{~nm}$ (interval 10) dengan menggunakan spektrofotometer UV-Vis . Panjang gelombang maksimum dari hasil scanning panjang gelombang digunakan untuk penelitian selanjutnya.

Supernatant cilok diambil $1 \mathrm{~mL}$, ditambah dengan $1 \mathrm{~mL} \mathrm{H}_{2} \mathrm{SO}_{4}$ kemudian ditambah dengan buffer phosphate pH 12 dan ditambahkan $1 \mathrm{~mL}$ ekstrak kulit buah naga merah, kemudian dikocok hingga homogen dan didiamkan \pm 15 menit kemudian di ukur dengan panjang gelombang $(\lambda)=546$ dengan blangko buffer $\mathrm{pH}$

\section{HASIL DAN PEMBAHASAN}

Ekstraksi yang digunakan yaitu ekstraksi maserasi, Metode maserasi bertujuan untuk mengambil zat atau senyawa aktif yang terdapat pada suatu bahan menggunakan pelarut tertentu. Metode ini (maserasi) digunakan dengan mempertimbangkan sifat senyawa (antosianin) yang relatif rentan terhadap panas sehingga dikhawatirkan akan merusak bahkan menghilangkan senyawa yang akan dianaliasa. Antosianin merupakan zat warna alami, selain digunakan untuk pewarna makanan, antosianin juga dapat digunakan sebagai 
petunjuk adanya boraks pada makanan. Oleh asam kuat, boraks akan terurai dari ikatanikatanya menjadi asam boraks dan akan diikat oleh antosianin.

Perbandingan jumlah sampel dan pelarut pada proses maserasi sampel ini adalah $1: 5$, yaitu $10 \mathrm{~g}$ sampel dalam $50 \mathrm{~mL}$ pelarut asam sitrat $0.4 \mathrm{M}$, dan dimaserasi selama 2 jam. Penambahan asam sitrat berfungsi mendenaturasi membrane sel tanaman, yang kemudian melarutkan pigmen antosianin sehingga dapat keluar dari sel.

Penggunaan asam sitrat sebagai pelarut karena kondisi pelarut yang semakin asam dapat menyebabkan semakin banyak pigmen antosianin berada dalam bentuk kation flavilium atau oksonium yang berwarna dan pengukuran absorbansinya akan menunjukkan antosianin yang semakin besar (Fennema, 1996

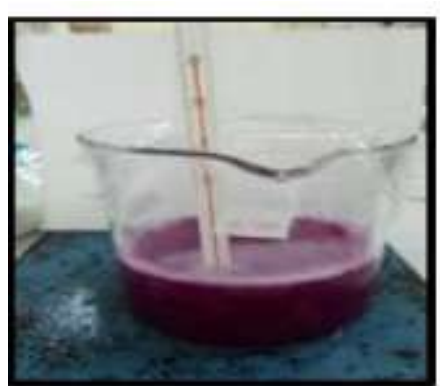

Gambar 4.1 Ekstraksi Maserasi

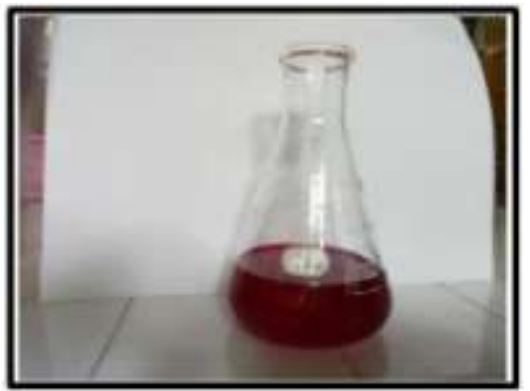

Gambar 4.2 Hasil ekstraksi Maserasi

Uji fitokimia dilakukan untuk mengidentifikasi senyawa antosianin berupa uji warna yang menggunakan pelarut $\mathrm{NaOH} 2 \mathrm{M}$ dan $\mathrm{HCl} 2 \mathrm{M}$. hasil dari uji fitokimia antosianin pada ekstrak kulit buah naga merah dibandingkan dengan Harborne(1987). Hasil uji fitokimia antosianin dapat dilihat pada Tabel 4.1.

Tabel 4.1 Uji Fitokimia Antosianin Ekstrak Kulit Buah Naga Merah

\begin{tabular}{|c|c|c|}
\hline \multirow{2}{*}{ Uji } & \multicolumn{2}{|c|}{ Hasil } \\
\cline { 2 - 3 } & Penelitian & Harborne (1987) \\
\hline Dipanaskan dengan HCl 2M & Warna tetap (bertambah & Warna tetap (merah) \\
selama 5 menit pada suhu 100 ${ }^{\circ} \mathrm{C}$ & pekat) & Warna berubah menjadi \\
\hline Ditambah larutan NaOH 2M \\
tetes demi tetes & Warna berubah menjadi & piru dan memudar \\
\hline
\end{tabular}


Salah satu faktor yang mempengaruhi warna dari antosianin adalah $\mathrm{pH}$. Sifat asam akan menyebabkan antosianin menjadi biru. Selain factor perubahan $\mathrm{pH}$, konsentrasi pigmen, adanya campuran dengan senyawa-senyawa lain, jumlah gugus hidroksi dan metoksi juga mempengaruhi warna antosianin (Satyatama, 2008). Gugus hidroksi yang dominan menyebabkan warna cenderung biru relatif tidak stabil, sedangkan gugus metoksi yang dominan menyebabkan warna merah dan relatif lebih stabil.

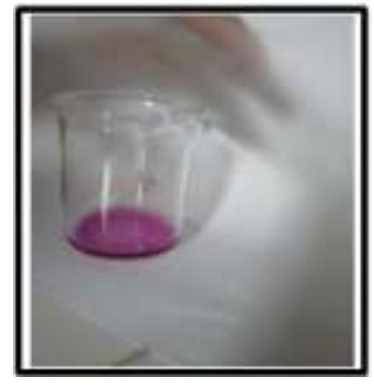

\section{Gambar 4.3 Warna ekstrak kulit buah naga merah}

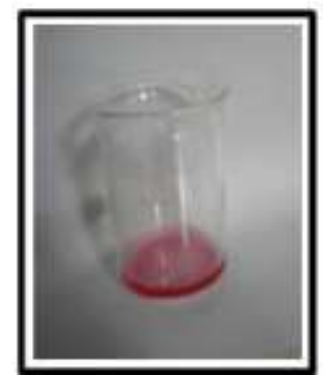

Gambar 4.4 Setelah ditambah HCL 2M

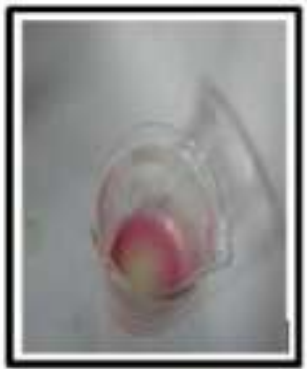

Gambar 4.5 Setelah ditambah larutan $\mathrm{NaOH} 2 \mathrm{M}$

Penentuan konsentrasi total antosianin dengan metode ini dilakukan karena pada $\mathrm{pH}$ 1,0 antosianin membentuk senyawa oxonium (kation flavilium) yang berwarna dan pada $\mathrm{pH} 4,5$ membentuk karbinol/hemiketal tak berwarna (Giusti M. M. and Wrolstad R. E., 2001). Kondisi inilah yang akan dijadikan acuan untuk menentukan absorbansi dengan menggunakan spektrofotometer UV-VIS dari masing- masing ekstrak yang di hasilkan. Perubahan warna pada antosianin dalam tingkatan $\mathrm{pH}$ tertentu disebabkan sifat antosianin yang memiliki tingkat kestabilan yang berbeda. Misalnya, pada pH 1,0 antosianin lebih stabil dan warna lebih merah dibandingkan $\mathrm{pH} 4,5$ yang kurang stabil dan hampir tidak berwarna.

Adapun struktur dan perubahan warna pada antosianin karena perbedaan tingkat PH, dapat di lihat pada gambar 4.6.
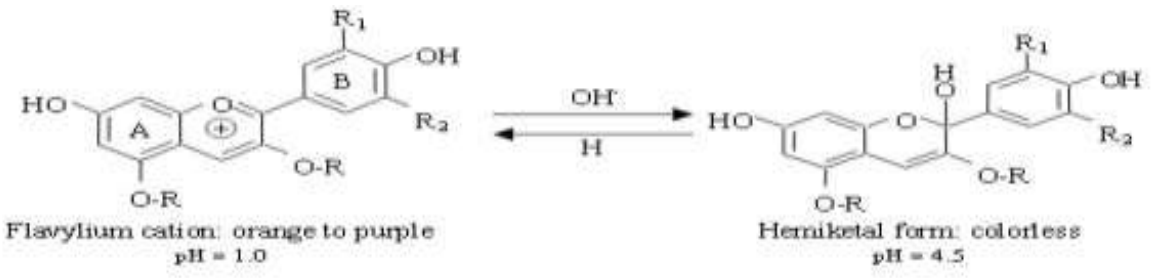

Gambar 4.6. Struktur Antosianin pada Kondisi pH 1,0 dan pH 4,5 (Wrolstad R,dkk., 2005). 
Adapun pada proses pengukuran antosianin dilakukan pada panjang gelombang (510 nm dan $700 \mathrm{~nm}$ ) untuk mencari titik nol. Panjang gelombang $510 \mathrm{~nm}$ adalah panjang gelombang maksimum untuk sianidin-3-glukosida, sedangkan panjang gelombang $700 \mathrm{~nm}$ untuk mengoreksi endapan yang masih terdapat pada sampel. Jika sampel benar-benar jernih maka absorbansi pada panjang gelombang $700 \mathrm{~nm}$ adalah 0 (Sutharut dan Sudarat, 2000).Pengamatan kestabilan warna dilakukan dengan mendiamkan larutan sebelum diukur selama jeda waktu $(0,15,30,45,60$ menit). Dari hasil penetapan senyawa antosianin dengan metode perbedaan pH ( $p H$ Differential) spektroskopi UV-Vis, Pada Gambar 4.7 menunjukkan bahwa kestabilan warna antosianin kulit buah naga merah, stabil pada waktu 0, 15, 30, 45 menit dan menunjukkan adanya penurunan kestabilan warna pada waktu 60 menit.

Waktu (menit)

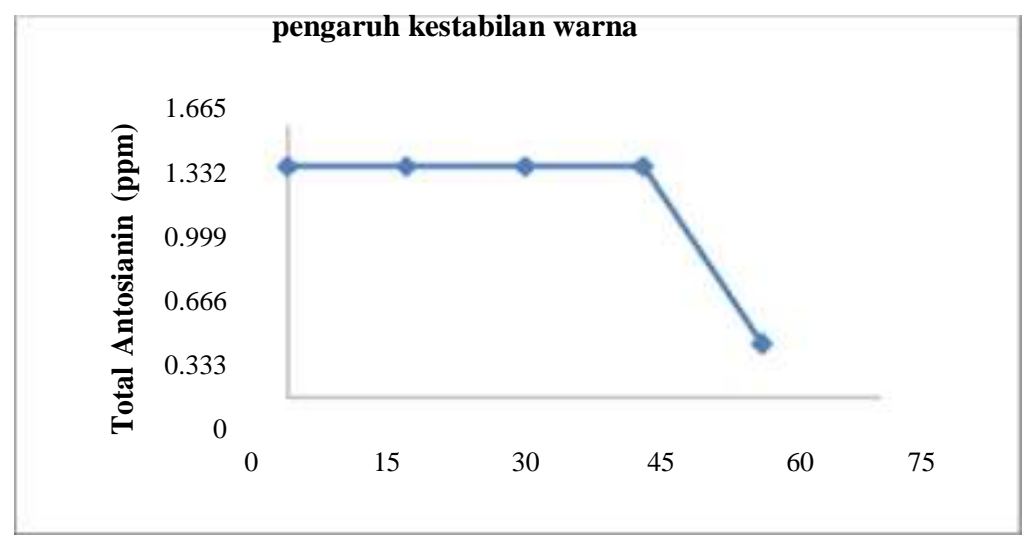

\section{Gambar 4.7 Grafik pengaruh kestabilan warna terhadap total antosianin}

Sedangkan penyimpanan pada kondisi dingin dapat menghambat terjadinya reaksi kopigmentasi dan reaksi pencoklatan tersebut Sehinga kepolaran suatu pelarut sangat perpengaruh pada estraksi antosianin kulit buah naga merah, Variasi pH yaitu 3 sampai 12.

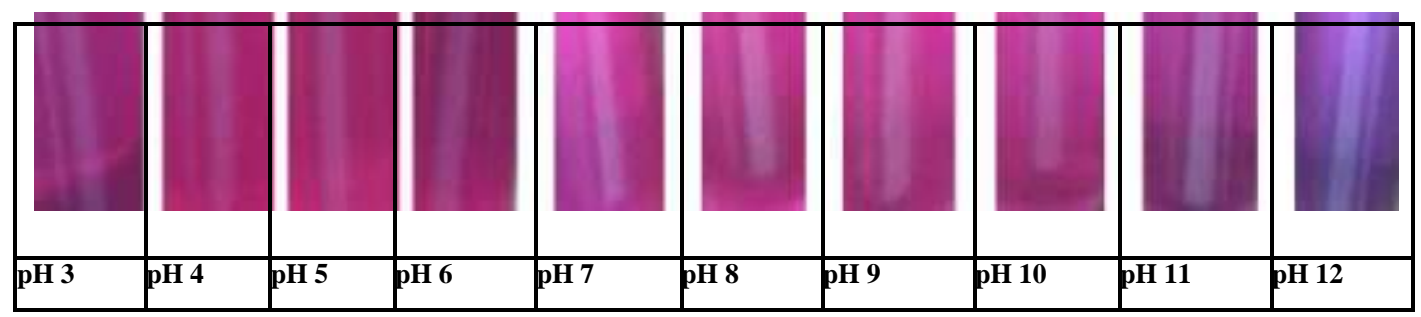

Gambar 4.8 Warna ekstrak buah naga merah setelah ditambahkan buffer

Jenis transisi $\mathrm{n} \rightarrow \pi$ pada molekul senyawa antosianin terjadi akibat adanya auksokrom yang terikat pada molekul. Auksokrom merupakan gugus fungsional yang mempunyai elektron bebas, seperti $-\mathrm{OH} ;-\mathrm{O}$; dan $-\mathrm{OCH}_{3}$. Terikatnya gugus auksokrom pada gugus kromofor akan 
mengakibatkan pergeseran pita absorpsi ke panjang gelombang yang lebih besar atau batokromik.

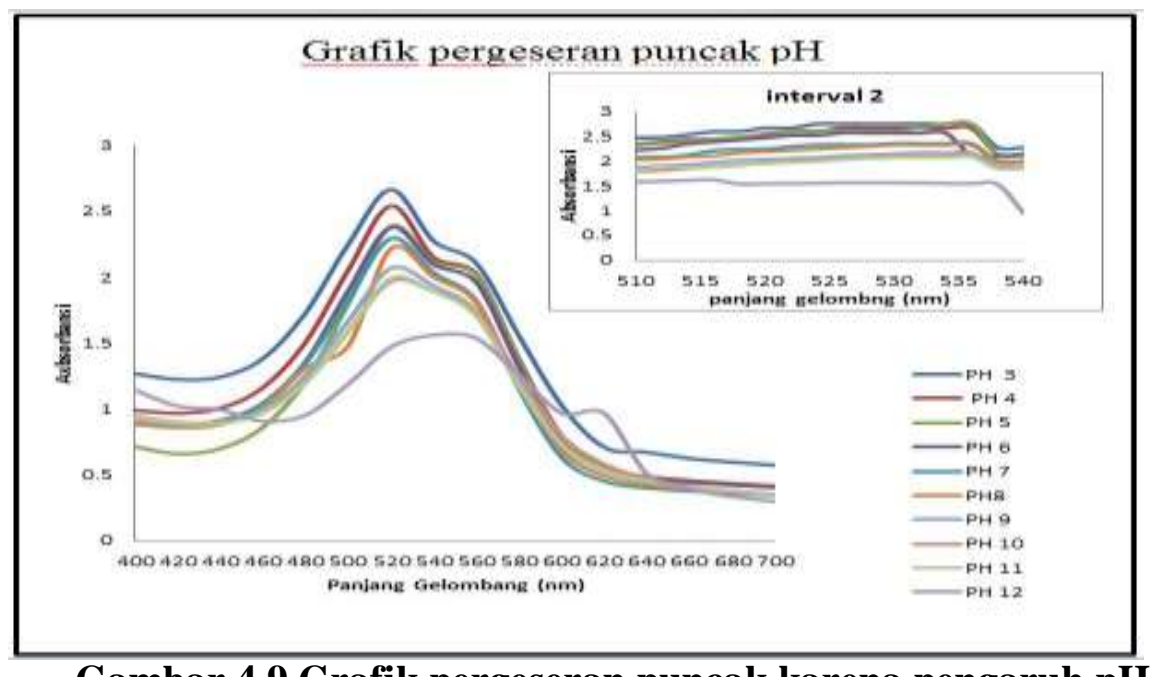

\section{Gambar 4.9 Grafik pergeseran puncak karena pengaruh pH}

Pada grafik diatas dapat dilihat bahwa semakin tinggi $\mathrm{pH}$ puncak absorbansi yang diperoleh semakin menurun (bergeser). Pada $\mathrm{pH} 3$ merupakan $\mathrm{pH}$ yang paling stabil dari struktur antosianin sehingga kandungan antosianin lebih tinggi dibandingkan pH 12 dan pH 7 (Dai dan Mumper, 2010). perubahan yang terjadi setelah penambahan larutan buffer 3 sampai 12 pada larutan menunjukkan perubahan warna yang hampir sama (gambar 4.8)

Perubahan warna tersebut terjadi karena perubahan struktur molekul antosianin akibat pengaruh $\mathrm{pH}$. maka digunakan $\mathrm{pH} 12$ untuk penelitian selanjutnya karena perubahan warna yang paling mencolok terdapat pada $\mathrm{pH} 12$.

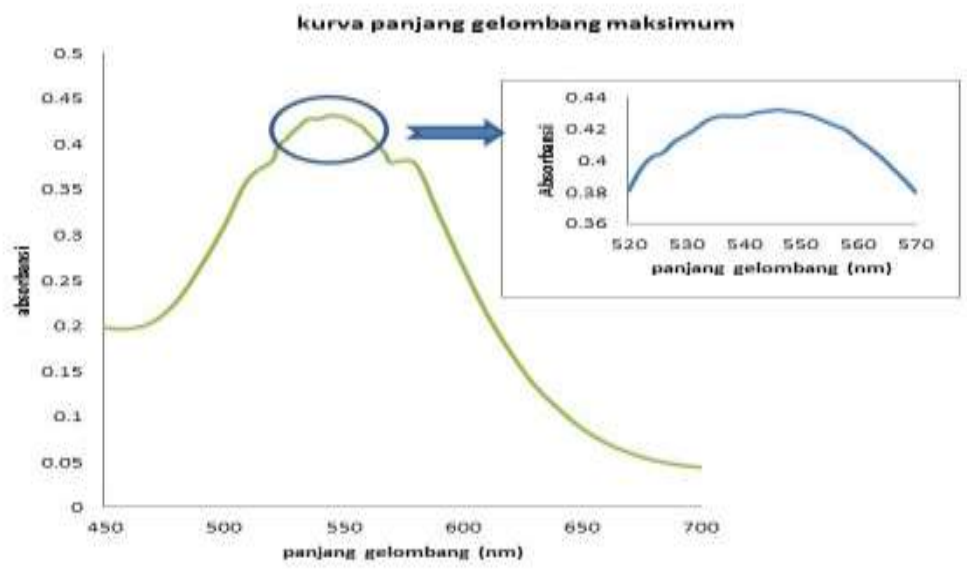

Gambar 4.10 Grafik kurva serapan panjang gelombang maksimum boraks 
Sampel cilok diperoleh dari pedagang cilok yang terdapat dipinggir jalan kota banyuwangi. Ekstraksi sampel dilakukan dengan menghaluskan sampel cilok, dan dicampur dengan pelarut yaitu air.

Identifikasi boraks dari supernatan tersebut dilakukan secara kuantitatif menggunakan spektofotometer UV-Vis.

boraks akan terurai dari ikatan-ikatannya dan menjadi asam boraks. Adapun reaksi yang terjadi antara larutan sampel boraks dengan $\mathrm{H}_{2} \mathrm{SO} 4$ adalah sebagai berikut :

\section{$\mathrm{Na}_{2} \mathrm{~B}_{4} \mathrm{O}_{7} 10 \mathrm{H}_{2} \mathrm{O}+\mathrm{H}_{2} \mathrm{SO}_{4} \longrightarrow 4 \mathrm{H}_{3} \mathrm{BO}_{3}+\mathrm{Na}_{2} \mathrm{SO}_{4}+5 \mathrm{H}_{2} \mathrm{O}$}

Asam boraks akan diikat oleh senyawa antosianin dan membentuk kompleks warna, kemudian ditambahkan buffer phosphate $\mathrm{pH}$ 12. Perubahan warna tersebut terjadi karena perubahan struktur molekul antosianin akibat pengaruh pH (Eskin, 1979).

Dari tabel 4.2 dengan kurva kalibrasi $\mathrm{y}=0.001 \mathrm{x}+0.002$ diketahui pada sampel cilok $\mathrm{A}$ terdapat total boraks sebesar 17,5 ppm, dan pada sampel cilok B total boraks sebesar $76 \mathrm{ppm}$.

Tabel 4.2 Hasil Uji Kadar Borak Pada Sampel Cilok dengan Spektrofotometer UV-Vis (panjang gelombang $=546 \mathrm{~nm})$.

\begin{tabular}{|c|c|c|c|c|}
\hline \multirow{2}{*}{ Sampel } & \multicolumn{3}{|c|}{ Absorbansi } & \multirow{2}{*}{ Arata-rata } \\
\cline { 2 - 4 } & $\mathbf{1}$ & $\mathbf{2}$ & $\mathbf{3}$ & \\
\hline $\mathrm{A}_{1}$ & 0.016 & 0.015 & 0.016 & 0.016 \\
\hline $\mathrm{A}_{2}$ & 0.015 & 0.015 & 0.015 & 0.015 \\
\hline $\mathrm{A}_{3}$ & 0.018 & 0.018 & 0.018 & 0.018 \\
\hline $\mathrm{B}_{1}$ & 0.077 & 0.078 & 0.077 & 0.077 \\
\hline $\mathrm{B}_{2}$ & 0.079 & 0.079 & 0.078 & 0.078 \\
\hline $\mathrm{B}_{3}$ & 0.077 & 0.077 & 0.077 & 0.077 \\
\hline
\end{tabular}

\section{Validasi Dengan Metode kualitatif}

Beberapa uji kualitatif yang dapat digunakan untuk analisis boraks, antara lain: reaksi dengan $\mathrm{H}_{2} \mathrm{SO}_{4}$ dan metanol pada abu sampel, reaksi kertas tumerik dan amonia dengan penambahan $\mathrm{H}_{2} \mathrm{SO}_{4}$ dan etanol, dan reaksi $\mathrm{H}_{2} \mathrm{SO}_{4}$ pada larutan sampel. Setelah kami melakukan uji kualitatif di laboratorium Dinas Kelautan Dan Perikanan Banyuwangi, pada sampel cilok A dan cilok B yang beredar di jalan raya Kota Banyuwangi positif mengandung boraks, dengan melihat hasil uji laboratorium pada tabel 4.3 
Sampel yang mengandung boraks setelah dilakukan uji nyala api akan terbentuk nyala api berwarna hijau yang disebabkan oleh terbentuknya metil borat $\mathrm{B}\left(\mathrm{OCH}_{3}\right)_{3}$ atau etil borat $\mathrm{B}\left(\mathrm{OC}_{2} \mathrm{H}_{5}\right)_{3}$.(18) Reaksi yang terjadi sebagai berikut :

$$
\mathrm{H}_{3} \mathrm{BO}_{3}+{ }_{3} \mathrm{CH}_{3} \mathrm{OH} \rightarrow \mathrm{B}\left(\mathrm{OCH}_{3}\right)_{3} \uparrow+{ }_{3} \mathrm{H}_{2} \mathrm{O}
$$

Sampel yang mengandung boraks setelah dilakukan uji dengan kertas tumerik akan berwana coklat-kemerahan (Fuad, 2014).

\section{Kesimpulan Dan Saran}

\section{Kesimpulan}

antosianin stabil pada $\mathrm{pH}$ asam yaitu $\mathrm{pH} 3$ dan pergeseran puncak $\mathrm{pH}$ paling signifikan terdapat pada $\mathrm{pH}$ 12. Kondisi kestabilan warna ekstrak antosianin dari kulit buah naga merah stabil pada waktu 0, 15, 30 dan 45 menit dengan total antosianin sebesar $1.419 \mathrm{mg} / \mathrm{L}$. Dari hasil pengukuran panjang gelombang maksimal diperoleh $\lambda=546 \mathrm{~nm}$ dengan serapan sebesar 0,432 , kemudian dapat diperoleh kurva kalibrasi dengan regresi $\mathrm{y}=0,0018 \mathrm{x}+0,025$ dengan $\mathrm{R}^{2}=0,9936$.

\section{Saran}

Perlu penelitian lebih lanjut tentang pengembangan metode Spektofotometer UV-Vis untuk Perlu dilakukan analisis kandungan pengawet lain pada cilok yang beredar di jalan raya Kota Banyuwangi. Perlu adanya sosialisasi kepada masyarakat mengenai bahaya kandungan boraks.

\section{Daftar Pustaka}

Belitz, H. D. and Grosch, W., 1999, Food Chemistry, 2nd Edition, Springer, Germany Citramukti, I. 2008. Ekstraksi dan uji kualitas pigmen antosianin pada kulit buah naga merah (Hylocereus costaricensis.). Skripsi.Jurusan Teknologi Hasil

Pertanian, Fakultas Pertanian, Universitas Muhammadiyah Malang. Malang.

Dreisbach, R.H.Handbook of Poisoning, $8^{\text {th }}$ ed. Lange Medical Publication,Los Altos, Calirornia.1974; 314-315

Flanaga, R.J.,Braithwaite,R.A.,Brown,S.S.,Widdop,B.,de Wolff,F.A.Basic Analytical Toxicology, World Healt Organization. Geneva1995; 85

Fuad, N.R., 2014, Identifikasi Kandungan Boraks Pada Tahu Pasar Tradisional Di Daerah Ciputat: Skripsi. Jakarta. Fakultas Kedokteran dan Ilmu Kesehatan 
Goodman, LS, Gilman, A. The Pharmacological Basis of Therapeutics $5^{\text {th }}$ ed. Macmillan Publishing Co.,Inc,NY.1975; 994 - 995.

Gosselin, R.E.,Smith,Robert P.,Hodge,H.C.,Clinical Toxicology of Commercial Products, $5^{\text {th }}$ ed London.66-68.

Haddad, L.M.,Winchester,J.F. Borats on Clinical Management of Poisoning and Drug Overdose. WB Saunders Co. Philadelphia-London-Montreal- Toronto-Sydney-Tokyo.1990; 1447-1449.

Harborne, J. B.,1987, Metode Fitokimia Edisi ke-2, a.b. Padmawinata, K., Soediro, I., Institut Teknologi Bandung, Bandung

Hendayana, Sumar.1994.Kimia Analitik Instrumen.Semarang:IKIP Semarang Press. Khopkar, S. M. 1983. Konsep Dasar Kimia Analitik (Terjemahan). Bombay : Indian

Institute of Technology.

Kristanto, D. 2008. Buah Naga: Pembudidayaan di Pot dan di Kebun. Jakarta: Penebar Swadaya,

Li, C.W., et al. 2006. Antioxidant and antiproliferative activities of red pitaya. Journal Food Chemistry. Vol 95: 319-327.

Markakis, P. 1982. Anthocyanins as Food Additives. Di dalam Anthocyanins as Food Colors. Markakis, P. (ed). 1982. Academic Press. New York.

Mulyono, HAM. 2012. Membuat Reagen Kimia di Laboratorium. Jakarta : PT Bumi AksaraNaderi, Nassim et al. 2012. Caracterication and Quantification of Dragon Fruit (Hylocereus polyrhzus) Betacyanin Pigments Extracted by Two Procedures. Pertanika J.Trop.Agric 35(1): 33-40.

Moulana, R, Efektivitas Penggunaan Jenis Pelarut dan Asam dalam Proses Ekstraksi Pigmen Antosianin Kelopak Bungan Rosella, Jurnal Forum Teknik , Universitas Syah Kuala, Darussalam, Banda Aceh, Vol 4, No 3, 2012.

Putra, A.K. 2009. Formalin dan Boraks pada Makanan. Bandung: Institut Teknologi Bandung Rein, M., 2005, Copigmentation Reactions and Color Stability of Berry Anthocyanin, Academic Dissertation, Helsinki: University of Heslinki

Reynold, J. E. F. Martindale The Extra Pharmacopoeia, $28^{\text {th }}$ ed. The pharmaceutical Press. London. 1982; 337, 432.

Swastika, S., Y. Nurmili dan S. Suhendri. 2012. Hama dan Penyakit Buah Naga. Balai Pengkajian Teknologi Pertanian Riau - Badan Penelitian dan Pengembangan Pertanian Kementerian Pertanian. Pekanbaru

Svehla, G. 1990. Vogel : Buku Teks Analisis Anorganik Kualitatif Makro dan Semimikro. Bagian II. Jakarta : PT. Kalman Media Pustaka 
Tensiska, dkk., Ekstraksi Pewarna Dari Buah Arben dan Aplikasinya dalam Sistem Pangan, Jurnal Teknologi Pangan Fakultas Pertanian, UNPAD, Vol 6, 2006.

Vargas, F. Natural Pigments: Carotenoids, Anthocyanins, and Betalains-Characteristics, Biosynthesis, Processing, and Stability. Critical Reviews in Food Science and Nutrition.2000; 40 Waladi et al. 2015. Pemanfaatan Kulit Buah Naga Merah (Hylocereus polyrhizus) Sebagai Bahan Tambahan Dalam Pembuatan Es Krim. Jom Faperta, Vol. 2, No. 1.

Winarno,F.G dan Titi Sulistyowati," Bahan Tambahan Untuk Makanan dan

Kontaminasi”, Pustaka S SinarHarapan, Jakarta,1992,101-08

Winarno, F.G.,Sulistyowati, Titi. Bahan Tambahan untuk Makanan dan Kontaminan. Pustaka Sinar Harapan. Jakarta. 1994; 104-105, 108.

Woodward,G, et al. 2009. "Anthocyanin stability and recovery: implications for the analysisofclinical and experimental samples".J. Agric. FoodChem.57(12):5271-8. 